\title{
Herta Müller e o ensaísmo autobiográfico na literatura contemporânea em língua alemã'
}

\author{
[Herta Müller and autobiographical essaysm in contemporary literature in German]
}

\section{Rosvitha Friesen Blume ${ }^{2}$}

\begin{abstract}
The current paper discusses Herta Müller's poetry essays in the context of contemporary autobiographical German writing. The question of referentiality of her essays will receive special attention; in these writings several aesthetic characteristics of autobiographical composition will also be shown. Furthermore, it will be demonstrated to what extent the effect of her essayistic writing is not only aesthetic, but also and mainly political.
\end{abstract}

Keywords: Herta Müller's poetry essays, contemporary autobiographical writing, autobiographical essayism

Resumo: No presente artigo discute-se o ensaísmo poetológico de Herta Müller no contexto da escrita autobiográfica alemã contemporânea. A questão da referencialidade de seus ensaios receberá especial atenção; nesses textos também serão apontadas as diversas características estéticas da composição autobiográfica. No mais, demonstra-se em que medida o efeito de sua escrita ensaística não é somente estético mas também e, principalmente, político.

Palavras-chave: ensaios poetológicos de Herta Müller, escrita autobiográfica contemporânea, ensaísmo autobiográfico

\footnotetext{
${ }^{1}$ Este artigo foi elaborado no âmbito de um estágio pós-doutoral na Albert-Ludwigs-Universität Freiburg, Alemanha, sob a supervisão da Profa. Dra. Michaela HoldENRIED, com bolsa CAPES - Proc. $n^{\circ}$ : BEX 9087/11-7.

${ }^{2}$ Professora no curso de Letras Alemão e na Pós-Graduação em Estudos da Tradução da UFSC. Email: rosvithafriesenblume@gmail.com
} 


\section{$1 \bigcirc$ autobiografismo na contemporaneidade}

O autobiografismo comporta uma grande variedade de gêneros textuais na contemporaneidade. Na autobiografia tradicional considera-se que a vida ali narrada, geralmente em retrospectiva e com o intuito de oferecer uma visão coesa da formação e atuação do protagonista, coincida com a vida do próprio autor da narração; já no romance autobiográfico postula-se um intenso processo de ficcionalização da própria vida, podendo ou não, nesse tipo de narrativa, tratar-se de fatos vividos pelo seu autor ${ }^{3}$. Dentre as modalidades autobiográficas, as cartas, as memórias e os diários são formas tradicionais de registro de trechos ou fragmentos da própria vida. As cartas têm um caráter mais dialógico, as memórias visam mostrar a relação do indivíduo com o seu meio social e os diários constituem uma forma mais introspectiva de narração da vida ${ }^{4}$. Os novos gêneros da era digital, como blogs e redes sociais, entrevistas e talk shows são novas maneiras de trazer fatos da própria vida a público e têm merecido igualmente a atenção de teóricos da escrita autobiográfica ${ }^{5}$. Mesmo o gênero textual do ensaio, tradicionalmente mais teórico-reflexivo, tem apresentado, nas últimas décadas, um crescente teor de narração autobiográfica ${ }^{6}$.

Pode-se dizer que a necessidade de narrar a própria vida está mais em voga do que nunca. Os limites entre a esfera privada e a pública diluem-se. Felicitas Hoppe ${ }^{7}$ afirma que "[a] nossa sociedade é aficionada pela confissão pessoal, seja ela de natureza política, literária ou pessoal. Assim se cria, por vezes, uma atmosfera quase terapêutica entre o autor e seu público." ${ }^{8}$ (HOPPE 2009: 46) Sibylle LEWITSCHAROFF ${ }^{9}$ arrisca uma

\footnotetext{
${ }^{3}$ Um dos estudos mais completos sobre o moderno romance autobiográfico é o de HOLDENRIED (1991).

${ }^{4}$ HoLDENRIED (1991) também trata desses gêneros.

5 Por exemplo, as teóricas SMITH E WATSON (2010) exploram muito bem essas novas textualidades autobiográficas do século XXI.

${ }^{6}$ Enquanto HoLDENRIED (1991) afirma que o ensaio autobiográfico é uma forma textual muito rara, podese observar uma mudança de tendência a esse respeito, conforme o presente texto procura demonstrar.

${ }^{7}$ HOPPE é escritora e vencedora do "Büchnerpreis" de 2012, o mais renomado prêmio literário da Alemanha atualmente.

${ }^{8}$ A autora afirma mesmo que "o motor da literatura é, desde sempre, o pessoal e não o geral." (HOPPE, 2009:218) / A tradução de todas as citações em alemão e inglês é de Rosvitha Friesen Blume.

${ }^{9}$ LEWITSCHAROFF também é uma escritora alemã de grande destaque na atualidade.
} 
Blume, R. - Herta Müller e o ensaísmo autobiográfico

explicação para tal fenômeno, dizendo que essa literatura que fala da própria vida do autor, "satisfaz uma necessidade de verdade num mundo caracterizado por uma radical falta de confiabilidade e de grandes dificuldades de encontrar nele algo que possa valer como verdadeiro - mais ainda, uma verdade estável.” (LEWITSCHAROFF 2012:33)

Por outro lado, Michaela Holdenried aponta para a crescente ficcionalização do gênero autobiográfico nos últimos trinta anos (HoLDENRIED 1991: 1) e afirma que a função básica dessa ficção na escrita autobiográfica seria a de esboçar, primeiramente, um “paradigma de identidade.” (HoLDENRIED 1991: 200)

\begin{abstract}
Como tarefa e propósito do autobiografismo moderno não está mais em primeiro lugar o apanhado de uma identidade pronta ou a repetição rememorativa dos passos individuais de sua gênese, mas a aproximação ao indisponível também do passado rememorado: ao perdido, esquecido, recalcado, mas também ao não-experimentado, não-reconhecido, não-sabido. Somente formas imaginativas de rememoração podem colocar esse aindanunca-sido no direito do potencial possivelmente-sido. (HOLDENRIED 1991:237)
\end{abstract}

Não se trata, pois, de recuperar e registrar "lembranças autênticas", porém, de refletir a respeito das formas possíveis e dos processos de rememoração. Sobre a escrita autobiográfica de infância, por exemplo, a teórica afirma:

Há um reconhecimento de que não se pode apanhar e reencontrar a experiência, a infância em sua factualidade vivida, em sua "sensação de existir", mas apenas as ideias criadas a respeito no decorrer de muitas fases de rememoração. Esse reconhecimento torna-se literariamente produtivo, ao se transferir o peso maior para o aspecto da representação ao invés do conteúdo. (HOLDENRIED, 1991:230)

Fazendo um resumo do desenvolvimento, desde o início do século $\mathrm{XX}$, das teorias em torno do gênero autobiográfico, Martina WAGNER-EGELHAAF destaca as noções de "figuração do real" e de "ficcionalidade literária" como os dois polos em torno dos quais gravitam as discussões. A argumentação teórica sobre o assunto mostra que, de uma preocupação centrada na "verdade histórica", passou-se gradativamente para uma atenção aos princípios constitutivos desse gênero textual, ou seja, "a autobiografia transformou-se de um documento histórico em uma obra artístico-literária.” (WAGNEREGELHAAF 2000: 39-40) 
Blume, R. - Herta Müller e o ensaísmo autobiográfico

Também Beatrice SANDBERG destaca que, a partir dos anos 70 do séc. XX, surgiu uma nova compreensão a respeito de conteúdo, forma e função da escrita autobiográfica: "No lugar do ideal de inteireza e de processos concluídos entram a limitação a aspectos isolados, a renúncia à pretensão de uma verdade universal e a abertura a contingências." (SANDBERG 2004: 164) A pesquisadora chama igualmente a atenção para a diluição dos limites entre realidade e ficção, mostrando que as construções identitárias se dão através do processo da escritura. "As próprias experiências subjetivas passam a ser mais valorizadas e encontram mais e mais espaço na 'polifonia dos discursos' que permeiam o assim chamado mundo pós-moderno." (SANDBERG 2004: 165).

Holdenried divide os gêneros autobiográficos pertencentes ao campo da literatura em dois grupos, os de caráter mais narrativo, como as memórias, as lembranças pessoais e o romance autobiográfico, e os mais ensaístico-reflexivos, como o diário, a carta, a série ou o arquivo de cartas e o ensaio autobiográfico. (HoLDENRIED 2000: 35) Mas ela também destaca que mesmo este último não se apresenta puramente reflexivo, contendo, ao contrário, cada vez mais traços de narratividade. (HoLDENRIED 1991: 126s) No presente artigo, uma acurada análise do ensaísmo autobiográfico de Herta Müller deverá exemplificar as características da escrita autobiográfica contemporânea mencionadas acima.

\section{Conferências e ensaios poetológicos}

O ensaísmo, especialmente o de natureza poetológica, têm sido parte integrante da produção de muitos escritores contemporâneos na literatura de língua alemã. Frequentemente esses textos são concebidos e apresentados primeiramente como conferências sobre poética e, mais tarde, adaptados ao registro escrito, sob forma de ensaio. Na Alemanha há uma tradição, ainda um tanto recente, de docências sobre poética realizadas por autores a convite de diversas universidades, numa busca pelo diálogo e maior integração entre a teoria e crítica literárias e a produção literária 
Blume, R. - Herta Müller e o ensaísmo autobiográfico

propriamente dita. Conforme Paul-Michael LÜTZELER (1994), a proposta dessas conferências é que os autores explanem a poética que rege seus processos criativos, ou que ao menos proporcionem aos estudiosos da literatura um olhar sobre sua prática de criação literária. $^{10}$

A Universidade de Frankfurt, num projeto conjunto com a editora Fischer, iniciou essa tradição em 1959, convidando a escritora austríaca Ingeborg Bachmann para proferir uma série de conferências sobre poética. Essa prática logo floresceu e vários outros autores foram convidados. Em 1968, com a revolta estudantil, interromperam-se as conferências. Segundo LÜTZELER (1994), os jovens que, naquele momento, estavam fortemente engajados em lutas políticas, não viam na literatura um meio suficientemente efetivo para promover as mudanças almejadas. Só em 1979 foram retomadas essas conferências sobre poética, que também se expandiram para diversas outras universidades da Alemanha, Áustria e Suíça.

O ensaísmo poetológico tem longa tradição na literatura de língua alemã; LÜTZELER (Id.) apresenta exemplos desde o barroco, com nomes como Martin Opitz, passando pelo classicismo e romantismo, com Friedrich von Schiller, Friedrich Schlegel, até chegar aos modernos, com Hermann Broch, por exemplo. Porém, segundo o teórico, tratava-se, nos séculos anteriores, da exposição de questões de estética de maneira objetiva e científica. Em relação às conferências sobre poética a partir de 1959, Lützeler afirma que "os autores das primeiras conferências haviam procurado reformular, para o seu tempo, as relações entre ética e estética postuladas pelos modernistas.” (LÜTZELER 1994: 9) Já o ensaísmo poetológico dos anos 1980 mudou consideravelmente, segundo o teórico. Inseridas no contexto da pós-modernidade, essas conferências têm sido caracterizadas por uma crescente tematização da subjetividade de seus autores, pela autorreflexidade, pela fragmentação e por elementos autobiográficos. Lützeler chega a afirmar até mesmo que "na condição pós-moderna a poética autobiográfica tornou-se a regra”. (Id.: 10-11) Ainda conforme o estudioso, nesse tempo

\footnotetext{
${ }^{10}$ Em sua primeira conferência sobre poética no ano de 1989, o autor Jurek Becker formula da seguinte maneira o objetivo dessas conferências: "Na verdade acredito que o sentido dessa docência seria mais ouvir os pássaros cantarem o seu trinado e assistir aos seus voejos e não tanto encontrar diletantes especialistas em pássaros pela frente.” (BECKER 1990: 9)
} 
Blume, R. - Herta Müller e o ensaísmo autobiográfico

[...] [o]s estudantes perceberam que categorias da estética moderna como totalidade, representabilidade e tipologia não tinham mais validade comum. Assim, eles ficaram ávidos pela visitação das oficinas, pelos relatos autobiográficos e pelas autointerpretações de autoras e autores contemporâneos. (LÜTZELER 1994: 10)

O que Lützeler afirma aqui também confirma as declarações de Hoppe e de Lewitscharoff citadas acima.

Segundo Doren Wohlleben, o formato das conferências sobre poética está sendo “cada vez mais literarizado" e se "pratica no nível do como aquilo que desde o início da segunda fase da docência sobre poética no ano de 1979 está tematizado no nível do quê, a saber, a função constituinte do narrar, lembrar, fingir.” (WOHLLEBEN 2005: 14) [grifos meus]. Portanto, ao se teorizar sobre a escrita autobiográfica, o "como", tematiza-se, ao mesmo tempo, a própria vida, o "o quê" de que fala Wohlleben. Ela afirma que "[v]ida e teoria, expressividade e reflexão, poesia e ciência, pretensão de objetividade e caráter subjetivo mantêm um frágil equilíbrio no ensaio.” (Id.: 26) A teórica destaca ainda que "a crescente literarização do novo gênero [conferência sobre poética], que agora apresenta cada vez mais traços autobiográficos, praticamente impossibilita uma distinção entre ficção e não-ficção" (Id.: 55-56). Em sua pesquisa, a autora dedica-se a explicar a "tensão produtiva" que se estabelece entre o que define como uma "poética literária", ou seja, textos teóricos sobre literatura em forma literária, e a "literatura poetológica", ou seja, uma literatura que teria como tema questões de teoria literária. (Id.: 12). No presente artigo, também deverá ser examinada essa tensão na produção ensaística de Herta Müller.

Para Lützeler as conferências sobre poética analisadas em seu livro Poetik der Autoren (1994) "refletem e discutem a diversidade, o pluralismo da literatura pósmoderna." (LÜTZELER 1994: 18) A partir dessa premissa, não se poderia postular uma "poética vinculatória" para os autores contemporâneos. (Id.: 16) Ao contrário, as influências do pensamento pós-moderno revelam-se através de uma grande diversidade na expressão literária. Segundo o teórico, “[o] resultado foi a assim chamada Nova Subjetividade com sua introspecção e o retrato biográfico de uma socialização individual problemática." (Id.: 9) As 'socializações problemáticas' narradas nessa literatura frequentemente dão-se em decorrência de uma concepção de educação 
Blume, R. - Herta Müller e o ensaísmo autobiográfico

autoritária experimentada por aquela geração de autores, o que, no entanto, se aborda de um ponto de vista subjetivo e individual. HoLDENRIED destaca que "[a]s autobiografias da infância mostram hoje quase exclusivamente histórias de feridas da tenra idade."11 (HoLDENRIED 1991: 170) A tematização de infâncias problemáticas que aparece com frequência na prosa literária desse período reflete-se também nas conferências sobre poética. Herta Müller é um bom exemplo dessa tendência; ela fala recorrentemente, também em seus ensaios, como se deverá mostrar no presente artigo, sobre a sua infância problemática. Segundo Clemens OTTMERS isso lhe permitiria, dada a distância temporal, "conhecer reflexivamente o passado e superá-lo através da linguagem [...]." (OTTMERS 1994: 284).

Discutindo a questão da referencialidade das conferências sobre poética na contemporaneidade, Lützeler afirma que as manifestações autobiográficas desses textos se referem "ao próprio autor, não a um terceiro, por mais subjetivas, mais seletivas e estilizadas que sejam essas declarações pessoais"; diz, também, que o ouvinte de uma conferência sobre poética aceita o "pacto autobiográfico" de Lejeune ${ }^{12}$, isto é, a identidade entre autor, narrador e personagem. Ainda assim, o teórico chama a atenção para a problematização do sujeito autoral, própria da pós-modernidade, também nessas conferências tão acentuadamente autobiográficas, que deixam entrever "a historicidade, o condicionamento e a fragmentação" desse sujeito, ao contrário de uma concepção idealista de sujeito (LÜTZELER 1994: 11).

Também WoHLLEBEN aborda a questão do sujeito autoral nas conferências sobre poética de autores contemporâneos. A autora menciona igualmente o "pacto autobiográfico", só que problematiza ainda mais sua aplicabilidade para esse tipo de texto. Sobre os autores dessas conferências afirma:

Suas declarações não são nem autobiográficas nem ficcionais. $O$ pacto autobiográfico chega aos seus limites aqui tanto quanto a distinção teórica entre autor e autor implícito no texto, que fazem parte dos axiomas da teoria literária. Nem os escritores docentes de poética concordam com uma separação estrita

\footnotetext{
${ }^{11}$ Um exemplo inverso comprova essa afirmação de Holdenried:a escritora Felicitas Hoppe se queixa de haver sido levemente discriminada pela crítica literária por " não ter nada para contar" [grifos da autora] a esse respeito, já que tivera "uma infância feliz". (HopPe, 2009:113/111)

${ }^{12}$ Philippe Lejeune, importante pesquisador francês contemporâneo sobre o tema da autobiografia, que publicou em 1975 um livro com o título Le Pacte Autobiographique.
} 
Blume, R. - Herta Müller e o ensaísmo autobiográfico

entre autor e narrador em primeira pessoa como a filologia o realiza, nem querem dirimi-la de modo que se compreendam os elementos autobiográficos num sentido por demais privado. (WOHLLEBEN 2005:56)

A partir disso Wohlleben conclui que o contato direto e ao vivo de autores com o seu público leitor nessas conferências permite a esses leitores / ouvintes, longe de quaisquer "conceitos pré-modernos de verdade e de onisciência", vivenciarem uma autoridade autoral que se estabelece "a partir de uma relação viva - ao invés de objetiva - com a literatura", a partir da "necessidade de diálogo" que esse autor tem, a partir de "sua insegurança quanto à direção a tomar e sua prontidão para confrontar-se com descontinuidades e rupturas" (WOHLLEBEN 2005: 54). Também HoLDENRIED enfatiza que, na escritura autobiográfica contemporânea, "[a] exigência de verdade é transformada através da adoção de modelos ficcionais" e que, ao invés da verdade, se requer a "autenticidade, perfeitamente compatível com a ficcionalização." (HoldENRIED 2000: 14) Nesse sentido dever-se-á examinar aqui a questão da referencialidade nos ensaios de Herta Müller.

\section{$3 \bigcirc$ ensaismo autobiográfico de Herta Müller}

Herta Müller já realizou docências sobre poética em diversas universidades alemãs e mesmo na Suíça, ${ }^{13}$ além de haver proferido palestras de cunho poetológico em várias outras ocasiões, que mais tarde também foram publicadas sob forma de ensaios.

Esse ensaísmo poetológico de Müller, sem ser puramente teórico, insere-se no quadro contemporâneo da literatura de língua alemã por ser narrativo, literarizado e ficcionalizado, fragmentário e subjetivo; mais do que no caso de grande parte dos ensaios poetológicos de outros autores alemães contemporâneos, o ensaísmo de Müller é autobiográfico, como se procurará mostrar aqui.

Muitos autores teorizam a respeito da questão do autobiografismo em seus ensaios poetológicos, ao falar de sua importância e do modo como elaboram elementos

\footnotetext{
${ }^{13}$ Paderborn - 1989/90, Bochum - 1995/96, Bonn - 1996, Kassel - 1998, Tübingen - 2000 (junto com algumas outras autoras), Tübingen - 2001, Berlin - 2005, Zürich - 2007.
} 
Blume, R. - Herta Müller e o ensaísmo autobiográfico

autobiográficos em sua escrita ficcional. ${ }^{14}$ Mas poucos empregam, em seus ensaios, esses elementos com a intensidade que Herta Müller o faz. Sua teoria e prática literária estão intimamente imbricadas em seus ensaios. Ao lê-los, o leitor se defronta ora com trechos de uma narratividade altamente artística, ora com momentos em que a autora compartilha, de modo muito direto e por vezes espantosamente franco, as mais diversas experiências de sua vida. ${ }^{15}$ É em seus ensaios que ela conta, entre outros fatos, que seu pai era soldado nazista ou que ainda viveu 20 anos após o fim da guerra como alcoólatra; que a mãe, quando moça, passou cinco anos num campo de trabalhos forçados na Rússia onde sua melhor amiga, que se chamava Herta, morreu de fome; que ela própria foi ameaçada de tortura e morte em muitos dos interrogatórios da polícia secreta romena; que pensava em se suicidar nos anos de perseguição política do regime de Ceauscescu; que abortou duas vezes sem ajuda médica, contrariando a lei do ditador que exigia cinco filhos de cada mulher fértil no país; que roubava compulsivamente em lojas na Romênia como forma de compensar a liberdade roubada pelo Estado. Além disso, recorre com muita frequência a memórias de pequenas cenas do cotidiano de sua infância, que lhe servem como imagens para falar sobre os processos da linguagem e sobre a sua criação poética.

\subsection{Vida e escritura}

Esse é o círculo vicioso: eu procuro viver, para não ter de escrever. E, justamente porque procuro viver, tenho de escrever a respeito. (MüLLER 1991: 48)

Embora a autora desenvolva uma escritura toda baseada em suas vivências, ela "se recusa a um realismo figurativo simplório, criando mundos artísticos imaginários em seus contos autobiográficos, nos quais o leitor é magicamente envolvido.” (OTTMERS 1994: 28) [grifos meus]. Entretanto, pode-se afirmar que um processo semelhante

\footnotetext{
${ }^{14}$ Por exemplo, Felicitas HOPPE, que teoriza sobre o autobiografismo, mas praticamente não emprega elementos de sua biografia na coletânea de ensaios Sieben Schätze, resultante de conferências sobre poética proferidas na Universidade de Augsburg em 2008; Uwe TIMM, em sua coletânea de ensaios Von Anfang und Ende. Über die Lesbarkeit der Welt, publicação de uma série de conferências sobre poética na Universidade de Frankfurt em 2009, fala sobre o cunho autobiográfico de seus romances.

${ }^{15}$ Isso acontece de maneira muito acentuada nos ensaios da coletânea Hunger und Seide (1995).
} 
Blume, R. - Herta Müller e o ensaísmo autobiográfico

ocorre também em muitos trechos de seus ensaios. Em sua tese de doutorado Astrid SCHAU interpreta a obra de Müller "em sua totalidade como um projeto autobiográfico." (2003: 24). Ou seja, mesmo nos textos teóricos esse projeto está bem presente.

Vida e escritura se fundem de maneira indissolúvel em toda sua obra. Seu trabalho com a linguagem é um trabalho incessante com as suas vivências desde a mais tenra infância, passando pelos anos em que viveu sob a ditadura de Ceauscescu na Romênia, até o início e a atual vida na Alemanha. LÜTZELER afirma que Herta Müller vê "sua obra como resultado de exílio, desenraizamento e despatriação." (LÜTZELER 1994: 12).

Nascida em Nitzkydorf, um vilarejo de imigrantes alemães da região do Banato na Romênia, ela aprendeu a língua romena somente aos quinze anos, quando se mudou para a cidade de Timisoara a fim de estudar. Aos trinta e três anos, imigrou rumo à Alemanha, para fugir do então regime ditatorial de Nikolai Ceauscescu, pelo qual foi duramente perseguida por haver se recusado a colaborar com a Securitate, o temido serviço secreto romeno. Porém, embora fosse descendente de alemães, também não se sentiu inteiramente em casa na Alemanha. E sua literatura produzida após a vinda para a Alemanha também trata prioritariamente de suas experiências traumáticas vividas no passado ditatorial. Norbert Otto EKE aponta uma "tripla oposição" em que Herta Müller se encontrava como jovem escritora na Romênia: uma linguístico-etnológica, outra política e ainda outra literária. Essa constatação representava ao mesmo tempo um triplo não-pertencimento ou exclusão para a autora: do vilarejo com sua tradição alemã enquanto comunidade e língua minoritária na Romênia, da posição política reacionária desses romeno-alemães bem como do regime ditatorial de Ceauscescu, e do grupo de escritores romeno-alemães tradicionalistas (Cf. EKE 1991: 10). LÜTZELER resume essa exclusão da autora dizendo que "seu principal opositor é o conformismo coletivo." (1994: 13). A constante manutenção da postura de oposição também deverá ser um dos motivos para a sua escrita tão marcadamente autobiográfica e pode, assim, ser visto como mecanismo de autoafirmação, como processo de formação identitária. ${ }^{16}$

\footnotetext{
${ }^{16}$ A dissertação de mestrado de Elvine BologA, Identität bei Herta Müller: Schreiben als Mittel der Selbstbehauptung (2012) trata incisivamente desse tema.
} 
Blume, R. - Herta Müller e o ensaísmo autobiográfico

No ensaio “Aqui em casa, na Alemanha”, publicado em 2003, Herta Müller diz que alguns críticos literários alemães têm requerido dela uma mudança na temática de sua obra, esperando que ela finalmente abandone o seu passado romeno e volte sua produção literária para a Alemanha atual, onde, afinal de contas, vive há mais de 20 anos. Entretanto, para a autora parece não haver receita para o esquecimento; ela afirma não ter escolha: "Ao escrever, tenho de me manter ali onde estou mais ferida interiormente, senão é claro que não precisaria escrever" e, "[q]uanto mais olhos eu tenho para a Alemanha, mais o atual se conecta com o passado.” (MÜLLER 2003: 185). Numa entrevista de 1998, a autora já afirmava: "Eu não escolho o meu tema, ele é que me busca, senão, é claro que não precisaria escrever." (in HAINES/LITTLER 1998: 24). E em outro trecho da mesma entrevista ela foi ainda mais enfática: "O tema me foi imposto, eu não o escolhi. Assim como a vida me foi imposta. Não é uma livre decisão, e uma coisa condiciona a outra." (in HAINES/LITTLER 1998: 14).

Em 1989, em uma entrevista para um programa alemão de rádio, a autora fala a respeito de como começou a escrever, revelando a centralidade de seu autobiografismo e a escrita como resposta ou reação à sua experiência vivida:

[E]ra uma escrita contra essa identidade, também contra esse vilarejo do banatosuábio, contra essa infância sem fala que oprimia tudo. Eu sempre só anotei experiências, não mais do que isso, na verdade. Eu não havia me proposto a escrever algo sobre essa região, sobre essa população, nunca tive a impressão de ter algo como uma responsabilidade em relação a isso ou que deveria fazer algo em nome de algum grupo. Era a experiência que eu havia tido, era a minha história de vida. Eu reagi às minhas experiências e não erigi qualquer superestrutura para tal, não fiz qualquer construção para isso, e essa experiência também estou tendo aqui. Não me resta nada além de ter experiências diárias, ver coisas diárias e também aqui eu procuro reagir a essas coisas. (MÜLLER, 1989, apud EKE, 1991:11-12)

A autora esclarece como se dá na escrita sua reação à experiência vivida, em uma entrevista concedida em 1998, na qual empresta de Georges-Arthur Goldschmidt o termo "autoficcional" 17 para caracterizar sua obra no que diz respeito aos elementos autobiográficos nela contidos. Desse modo, ela deixa claro o quanto o seu assunto é determinado pela experiência por ela vivida, embora também aponte que essa

\footnotetext{
${ }^{17} \mathrm{O}$ conceito, na verdade, provém do teórico francês Serge Doubrovsky, porém, Goldschmidt o adota para caracterizar a sua própria obra.
} 
Blume, R. - Herta Müller e o ensaísmo autobiográfico

experiência passa antes por um rigoroso processo de ficcionalização: "Ora, eu não escrevi absolutamente nada em meus livros da maneira como aconteceu. Mas eu preciso dessa relação segura com a experiência para ir à ficção. [...] Talvez tenha de ter vivenciado vinte interrogatórios para inventar um." (in HAINES/LITTLER 1998: 14-15). Possivelmente a autora se refira aqui ao seu romance Heute wär ich mir lieber nicht begegnet $^{18}$, no qual a protagonista está a caminho de mais um interrogatório e relembra, em muitos flashbacks, interrogatórios anteriores.

Também em seus ensaios, o processo não parece ser muito diferente. Müller narra, por exemplo, no ensaio "O rei se inclina e mata" ${ }^{19}$, uma situação na qual ela e seus amigos na Romênia criam histórias irônicas, a fim de se divertirem com o regime e assim reprimirem o seu medo. A título de ilustração ela narra, no ensaio supracitado, uma dessas histórias, com riqueza de detalhes. Porém, ao final a autora admite abertamente: "Eu inventei essas frases agora porque já esqueci há muito tempo as de então. Mas elas poderiam ter sido assim.” (MüLlER 2003: 66). Como mostra a afirmação precedente, ocorre também um marcado processo de ficcionalização em seus ensaios, embora a autora, ao mesmo tempo, o tematize no nível reflexivo. E essa é uma característica muito própria dos ensaios de Herta Müller.

A relação entre palavra e experiência é, pois, objeto de reflexão incisiva em toda sua obra. Sobre a sua "infância sem fala" que ela menciona na entrevista citada acima, a autora também discorre no ensaio "Se nos calamos, tornamo-nos desagradáveis - se falamos, tornamo-nos ridículos", publicado em 2003:

Conheço de casa, entre os colonos, um modo de vida que não tinha por costume o emprego de palavras. [...] Cada frase só tem sua vez quando a anterior se foi. No calar tudo vem de uma vez só, tudo se acumula ali, o que por muito tempo não é dito e até mesmo o que nunca é dito. (MüLLER 2003: 74-75).

Depois vem o tempo da ditadura, que ela relembra como "uma vida por um fio, na qual sabia cada vez melhor o que não se pode dizer com palavras.” (MÜLLER 2003: 104). Por isso a autora reafirma seu esforço incessante de, "através da invenção, recortá-la [a

\footnotetext{
${ }^{18}$ O romance, publicado em 1997, foi traduzido para o português do Brasil com o título $O$ compromisso (vide referências bibliográficas).

${ }^{19}$ Esse ensaio dá título a uma coletânea de ensaios publicada pela autora em 2003 e que será publicado pela editora Globo Livros em 2013, com tradução de Rosvitha Friesen Blume.
} 
experiência] de modo irreconhecível, a fim de fazê-la caber na palavra" (MüLLER 2003: 104), como que em um gesto de afronta a esse silêncio imposto.

\subsection{Subjetividade e fragmentação}

Pedaços de mundo se desprendem, como se eu tivesse engolido tudo o que eu não posso carregar. (MÜLLER 1991: 34)

Conforme se vê pela declaração de Herta Müller ao programa de rádio, citada acima, sua escrita tem um caráter muito subjetivo; ela não quer narrar os grandes fatos históricos, mesmo que eles estejam presentes em seus livros. No ensaio "Como se inventa a percepção", de 1991, ela revela:

Percebo que em minha memória não permanece preferencialmente aquilo que aconteceu no plano exterior, que se denomina fato. $\mathrm{O}$ que permanece mais fortemente é aquilo que também lá estava na cabeça e que pode ser revivido, aquilo que vinha do interior em vista do exterior, dos fatos. (MÜLLER 1991: 10).

Não são os acontecimentos exteriores, portanto, que estão em primeiro plano, mas a sua percepção subjetiva, conforme aparece claramente em diversas declarações da autora sobre a sua obra. A respeito de um dos conceitos poetológicos centrais de Müller, o da “percepção inventada” (MÜLLER 1991: 13) que será tratado mais detidamente abaixo, Ottmers afirma: “A percepção de maneira nenhuma se dá objetivamente, no sentido de uma captação sumária do mundo exterior, entretanto, de um modo altamente seletivo e com base em critérios de seleção bastante subjetivos." (OTTMERS 1994: 281). Essa consciência é muito acentuada na obra poetológica de Müller.

A visão subjetiva da autora está sempre interessada no fragmento, no detalhe e na particularidade, conforme comenta no livro de ensaios Hunger und Seide, quando se refere especificamente a biografias de pessoas em situação de perseguição e fuga:

Biografias de fugitivos são nada mais do que incontáveis particularidades vividas. Não seria necessário conhecer as de milhares deles, só se precisaria saber o que está envolvido em poucas histórias de vida para compreender. 
Blume, R. - Herta Müller e o ensaísmo autobiográfico

Particularidades são precisão. Só elas podem ser comparativamente relacionadas com a própria vida. (MÜLLER 1995: 25, grifos da autora).

E ainda em outro ensaio, "Dez dedos não se tornam uma utopia"20, a autora discorre mais uma vez sobre a sua aversão a visões totalizantes da vida, insistindo numa percepção individual da história, subjetiva e fragmentária:

Mil detalhes produzem algo, mas não uma linha coerente da vida, nenhum acordo geral, nenhuma utopia. Detalhes não podem ser alinhados como peças de uma corrente ou em qualquer lógica linear do mundo. Nunca tive aptidão para o todo. Sempre procurava, com o maior desespero, imaginar como poderiam ser os detalhes que cruzavam o meu caminho. Isso nunca resultou numa teoria. (MÜLLER, 1995:61)

Brigid HAINES qualifica a obra de Müller como uma "micropolítica de resistência", que estaria voltada "teimosamente para o particular, o individual, o local, o detalhe", o que lhe serviria tanto como "estratégia estética" quanto como "mecanismo básico de sobrevivência" diante das "grandes narrativas do totalitarismo." (HAINES 1998: 109). E vale observar que essas "grandes narrativas" aludem não somente à ditadura de Ceauscescu, mas também ao discurso religioso e ao germanismo fanático com resquícios da ideologia nazista do vilarejo em que a autora se criou. Portanto, sua obra volta-se contra toda e qualquer utopia e não oferece, tampouco, uma "contra-utopia", como David MidGLeY bem observa, mas se concentra "no detalhe do que ela experimentou ao seu redor, em oposição a qualquer sentido que isso possa ter como um todo.” (Midgley 1998: 33). Com a atenção voltada ao fragmento, ao detalhe e à rejeição de retratos totalizantes de uma vida, a escrita de Herta Müller encontra-se em plena sintonia com a escrita autobiográfica contemporânea, conforme descrito com Sandberg no início desse artigo. No seu caso, porém, essa tendência configura-se como dupla estratégia, estética e política.

\footnotetext{
20 “Zehn Finger werden keine Utopie". In: Hunger und Seide (MÜLLER 1995: 50-61). Não disponível em português do Brasil.
} 
Blume, R. - Herta Müller e o ensaísmo autobiográfico

\subsection{A "percepção inventada"}

Daquilo que se experimentou, o dedo indicador na cabeça também escolhe ao escrever a percepção que se inventa. (MüLLER 1991: 20)

Embora afirme explicitamente que o elemento autobiográfico é importante em sua obra (MÜLLER 1991: 20), Herta Müller explica como compreende o trabalho de escrita a partir das experiências próprias em um de seus ensaios mais incisivamente poetológicos, chamado "Como se inventa a percepção", e que se concretizou a partir de sua primeira docência sobre poética, na Universidade de Paderborn. A coletânea que reúne os ensaios resultantes dessa docência é intitulada "O diabo está sentado no espelho" 21 , título esse que provém de um dado autobiográfico. A menina Herta ouvia tais palavras de sua avó quando se olhava no espelho. Esse dístico deveria servir-lhe de admoestação contra a vaidade; representaria também o interdito de uma percepção de si mesma ou da realidade externa que fugisse dos contornos extremamente padronizados do vilarejo natal. A partir dessas palavras de advertência, a autora constrói um de seus conceitos poetológicos centrais, o da "percepção inventada” (MÜLLER 1991: 13).

Algo inventado é, por princípio, algo não real nem verdadeiro. Já a percepção advém justamente de uma impressão despertada pelo real, por aquilo que foi ouvido, visto, sentido, portanto, algo que deveria ser verdadeiro. Assim, esse conceito "percepção inventada", em um primeiro momento, parece denotar uma contradição em si. Entretanto, ele serve a Müller justamente para explanar a relação entre realidade e ficção, que em sua obra é tão importante justamente por ter uma base tão marcadamente autobiográfica. $\mathrm{Na}$ exposição de seu processo criativo em torno do elemento autobiográfico fica claro, como também afirma EKE (1991), que a realidade é apenas um ponto de partida para essa "percepção inventada" 22 da autora. Isso se explica pelo fato de o processo de percepção não ser linear, mas se dar de modo mais ou menos aleatório: “A percepção que se inventa, não para quieta. Ela ultrapassa os seus limites lá onde ela

\footnotetext{
${ }^{21}$ Der Teufel sitzt im Spiegel. Não disponível em português do Brasil.

${ }^{22}$ O livro que Eke publicou 1991 e que reúne vários estudos fundadores para a pesquisa da obra de Herta Müller tem o título Die erfundene Wahrnehmung. Annäherung an Herta Müller. (vide referências bibliográficas)
} 
Blume, R. - Herta Müller e o ensaísmo autobiográfico

se segura. Ela não é intencional, não quer dizer nada definido. É embalada pelo acaso. No entanto, a sua imprevisibilidade acerta a única escolha possível quando ela se escolhe." (MÜLLER 1991: 19). O mencionado ensaio, "Como se inventa a percepção", inicia-se com a seguinte frase: "Às vezes eu acredito que cada um leva consigo um dedo indicador na cabeça." (MüLLER 1991: 9). Conforme a autora, esse " dedo indicador na cabeça" é completamente autônomo e aponta para o que quer. Segundo Ralph KöHNEN, a "percepção inventada" pode ser interpretada como "arbitrariedade de toda percepção, como percepção que dá forma, que leva a um engano fundamental sobre o mundo.”. Köhnen também ressalta que a "percepção inventada" da autora teria a função de “identificar o mundo percebido como apenas uma versão possível, como versão contingente do mundo" (KÖHNEN 2002: 27).

Segundo OTTMERS, a autora mostra nesse ensaio como se dá a transformação das experiências vividas em construções artístico-literárias que "reivindicam a sua própria 'realidade'.” (OTTMERS 1994: 281). E a própria autora também explica:

E assim acontece que, mesmo o autobiográfico, o próprio no sentido mais estrito da palavra, só tem a ver comigo de maneira mediata, só tem a ver com a minha autobiografia no sentido mais amplo da palavra. Já "pelo simples motivo de que, quando escrevo sobre mim, só tenho a ver comigo de modo mediato." (MÜLLER 1991: 43)

E isso Müller mostra a partir de vários exemplos. Um deles, muito contundente, é quando ela fala sobre a decepção de certos leitores que, ao visitarem Nitzkydorf a fim de conhecerem o cenário de seu primeiro livro de contos, Depressões, encontram, na realidade, um vilarejo comum, como qualquer outro. A autora reage irritada: “O vilarejo só existe nas Depressões" (MÜLLER 1991: 16-17).

Entretanto, ainda que alguns leitores se aproximem de seus textos de modo excessivamente ingênuo, procurando "verdade", existe algo de "verdadeiro" nesses escritos. A autora explica essa percepção de verdade no segundo ensaio da mesma coletânea de 1991, com o título "Como, em retrospectiva, o inventado é percebido/tomado como verdadeiro." ${ }^{23}$. Aqui a autora dá continuidade à reflexão sobre

\footnotetext{
${ }^{23} \mathrm{O}$ título em alemão, "Wie Erfundenes sich im Rückblick wahrnimmt", contém um jogo de palavras que procurei retratar na tradução do título através dos dois sentidos da palavra, separados por barra. $\mathrm{O}$ verbo 'wahrnehmen' significa 'perceber', mas ao mesmo tempo contém a palavra 'wahr', 'verdadeiro'. Seria,
} 
Blume, R. - Herta Müller e o ensaísmo autobiográfico

a questão do trabalho literário a partir das experiências vividas, e explica em que medida a "percepção inventada", ou seja, o texto literário, pode tornar-se 'verdadeiro': “[eu] só percebo que há situações que mais tarde saem das frases que eu escrevi e vão para a realidade." (MüLLER 1991: 49). Mesmo quando se refere à leitura de textos de outros autores Müller afirma: “A percepção inventada que a gente leu se prolonga. Ela é mais forte. Ela ocupa. Não são as imagens na cabeça que se tornam como um lugar, mas é o lugar que se torna como as imagens na cabeça." (MüLlER 1991: 53). O verdadeiramente literário tem, portanto, capacidade de convencimento, efeito, influência. Assim, também aqui Herta Müller mostra-se em pleno acordo com a teoria contemporânea da autobiografia, conforme visto acima com Holdenried: muito mais importante do que a exigência por "verdade" é a exigência por "autenticidade".

Müller atribui uma importante função a essa "percepção inventada”: “Talvez [...] a invenção da percepção fosse a única possibilidade de mudar o mundo ao meu redor. Ele não se tornou mais suportável. Ele tornou-se mais ameaçador. Porém, ao menos esse acréscimo tinha algo a ver comigo mesma." (MüLlER 1991: 29) Portanto evidencia-se, mais uma vez, uma busca da autora por si mesma, pela afirmação de si em um meio hostil; o trabalho de criação literária da autora, pelo caminho da ficcionalização, configura-se como reação necessária a uma experiência de vida adversa.

Esses e mais alguns outros ensaios da coletânea "O diabo está sentado no espelho" são os mais intrinsecamente poetológicos da autora. Entretanto, o caráter fragmentário e subjetivo desses textos não permite entrever uma poética pronta ou estruturada. Comentando esses ensaios, Eke diz que eles "seguem a lógica estética própria da dicção mülleriana. Eles mesmos, construídos literariamente, situam-se no limiar entre teoria estética e prática artística. O discurso poético e o teórico se interpenetram e aparecem como dois lados da mesma obra." (EKE 1991: 18)

Doze anos depois dessa primeira coletânea de ensaios de Müller, é publicada, em 2003, a coletânea intitulada "O rei se inclina e mata" ${ }^{24}$, que reúne, entre outros,

pois, um movimento contrário ao ensaio anterior, onde o real se tornara inventado. Aqui o inventado volta a ser verdadeiro.

${ }^{24}$ Entre esses dois volumes foram publicadas mais duas outras coletâneas de ensaios da autora, Hunger und Seide (1995) e In der Falle (1996). 
Blume, R. - Herta Müller e o ensaísmo autobiográfico

cinco ensaios provenientes das conferências sobre poética realizadas por Müller na Universidade de Tübingen em 2000 e 2001. Nesses textos, ela retoma a questão da referencialidade do texto literário, ou seja, da relação entre verdade e ficção, entre o real e o inventado, temas já amplamente explorados na coletânea de 1991. No ensaio intitulado "Se nos calamos, tornamo-nos desagradáveis - se falamos, tornamo-nos ridículos”, Müller escreve:

O vivido enquanto acontecimento não está nem aí com a escritura, não é compatível com as palavras. Os acontecimentos reais nunca podem ser apreendidos equitativamente com palavras. Para descrevê-los, os acontecimentos precisam ser modelados em palavras e completamente reinventados. Aumentar, diminuir, simplificar, complexificar, mencionar, passar por alto - uma tática que segue seus próprios caminhos e que tem o vivido apenas como pretexto. Quando se escreve, arrasta-se o vivido para outro metier. (MÜLLER 2003: 86)

O trabalho concreto com a linguagem é aqui explicitado muito detalhadamente e, através dele, o processo de textualização do vivido: “A gente testa qual palavra é capaz do que. Não se trata mais de noite ou dia, vilarejo ou cidade, mas o que domina são substantivo e verbo, oração principal e subordinada, compasso e som, linha e ritmo." (MüLLER 2003: 86) E o que acontece com o vivido nesse processo, Müller descreve da seguinte maneira:

O acontecimento real insiste enquanto aparição periférica; com palavras se lhe dá um choque após o outro. Quando ele mesmo não se reconhece mais, o acontecimento volta ao centro. Precisa-se demolir a presunção do vivido para se escrever sobre ele, desviar-se de cada rua verdadeira para uma inventada, pois só esta pode parecer-se com ela novamente. (MÜLLER 2003: 86)

Dessa maneira também podem ser lidos muitos trechos de seus ensaios. $O$ autobiográfico "se parece" com o vivido pela autora; esse ensaísmo satisfaz não uma exigência de verdade, mas de autenticidade. A "percepção inventada" é, pois, a base teórica para a sua escritura autobiográfica: Herta Müller apresenta não somente em sua obra ficcional propriamente dita mas também em sua obra poetológica o princípio da ficcionalização, característico da escrita autobiográfica contemporânea. Contudo podese dizer que Müller também se distingue de outros ensaístas alemães contemporâneos, 
Blume, R. - Herta Müller e o ensaísmo autobiográfico

cujos ensaios poetológicos são ricos em elementos autobiográficos ${ }^{25}$ na acepção da palavra; nesses textos não se encontra essa construção teórico-poetológica tão intensamente vinculada à sua autobiografia como no caso de Herta Müller.

\section{$3.4 \bigcirc$ "olhar obstinadamente próprio" e "estranho"}

[...] o olho do poder olhava para todo lugar. (MÜLLER 1991: 20)

Nesse cotidiano surgiu o olhar estranho. (MÜLLER 2003: 135)

Voltando à coletânea de 1991, na qual Herta Müller teoriza sobre a "invenção da percepção", vale resgatar uma interpretação do teórico Friedmar Apel a respeito do conceito. Ele lê a obra da autora a partir do que denomina uma "poética do olhar obstinadamente próprio" (APEL 1991: 22). E assim define a "invenção da percepção" da qual fala Müller em seu ensaio "Como se inventa a percepção". Trata-se do direito, requerido pela escritora de forma radical, de perceber o mundo para além dos limites impostos por aquilo que ela denomina "olho do poder", (APEL 1991: 25), ou seja, perceber para além da padronização imposta, para além da proibição, tanto na pequena comunidade alemã natal, quanto mais tarde na ditadura de Ceauscescu; advoga, assim, o direito de ser diferente. A radicalidade desse olhar promoveria o que o teórico considera “[a] unicidade da voz de Herta Müller na literatura alemã contemporânea” (APEL 1991: 23).

Nessa "poética do olhar obstinadamente próprio" APEL identifica uma dupla motivação, tanto estética quanto política, de resistir "[à] desapropriação dos sentidos" (APEL 1991: 31). Argumentando na mesma linha, Markus STEINMAYR diz que "o olhar dissector e fragmentador da percepção inventada abre a possibilidade para uma realidade tornada poeticamente estranha, que funciona como contraparte de um olho do poder que age de modo panóptico" (STEINMAYR 1997: 141).

\footnotetext{
${ }^{25}$ Um exemplo seria Horst Bienek que, em suas conferências sobre poética na Universidade de Munique em 1987, publicadas como ensaios em 1994, apresenta muitos trechos narrativos sobre suas experiências vividas, variando o relato entre uma narração em primeira e terceira pessoa.
} 
Blume, R. - Herta Müller e o ensaísmo autobiográfico

Esse "olhar obstinadamente próprio" é, pela sua radicalidade e diferença, um "olhar estranho" aos demais observadores ao redor da autora. E é assim que ela intitula um de seus ensaios publicados em 2003, "O olhar estranho", no qual explica que esse seu olhar não provém do fato de haver imigrado para a Alemanha ou de não se sentir em casa ali. Provém, sim, da perspectiva adquirida a partir de incontáveis experiências de perseguição que lhe roubaram a naturalidade diante da vida e das coisas. Objetos e situações comuns como uma bicicleta, uma geladeira ou uma descoloração de cabelo são revestidos de novos significados; eles têm a ver com ameaças de morte por atropelamento, no caso da bicicleta, com as marcas deixadas pelo serviço secreto em sua casa, quando um bilhete posto no trinco da porta pela amiga veio a parar sobre a geladeira, ou com um produto venenoso aplicado pela cabeleireira mancomunada com o serviço secreto, que the queimou o couro cabeludo. Conforme Herta Müller, "[a] perseguição não acontece somente quando se está no interrogatório. Ela está fincada nas coisas e nos dias que, por fora, não aparentam nada. Por isso a gente se desacostuma das partes da vida ausentes do dia, do casual, que se leva consigo por aí, sem julgamento e sem propósito." (MüLLER 2003: 137). São esses e muitos outros episódios semelhantes narrados pela autora em seus ensaios que produzem o que ela denomina o "olhar estranho" e que Apel considera "obstinadamente próprio".

\subsection{A "poética das coisas"}

Sempre nos encontramos despreparados diante das coisas. Sempre elas se inventam, enquanto fazemos algo. (MÜLLER 1991: 25)

Herta Müller fala repetidas vezes, em seus ensaios, sobre a importância que confere às “coisas" ou aos "objetos". Ainda no ensaio "O olhar estranho", comentado acima, a autora diz que "[o] acordo com as coisas é precioso porque nos poupa. Isso se chama naturalidade. Ela só existe enquanto não se sabe que se a tem.” (MüLlER 2003: 147). A opressão avança sobre a pessoa, sobre as coisas ou os objetos mais familiares que a cercam de modo a ressignificá-los negativamente. Ela chega à conclusão de que "quanto menos livre é um país, quanto mais se é observado por um Estado, com mais coisas se 
Blume, R. - Herta Müller e o ensaísmo autobiográfico

tem a ver, mais dia menos dia, de modo desagradável.” (MüLLER 2003: 137). Apel comenta esse trecho do ensaio da autora, dizendo que é essa a razão pela qual "as coisas [...] desempenham o papel decisivo no universo poético de Herta Müller.” (APEL 2002: 42). O teórico continua sua análise afirmando que "nas coisas, mesmo nas mais privadas, a relação do indivíduo com o Estado e a sociedade se torna concreta, ela se personifica nas coisas.” (APEL 2002: 42).

Para Simon TraUtMANN ${ }^{26}$, Müller, com a concentração nas coisas, mostra muito claramente "como ideologias poderosas exercem influência sobre a relação entre palavras e coisas, ou sobre a percepção das mesmas." (TRAUMANN 2011: 32). O crítico interpreta o significado das coisas na obra de Müller da seguinte forma:

Ao aparecerem como opositores de ordens estabelecidas, as coisas refletem no nível da estrutura textual o que é narrado constantemente na literatura de Müller: uma rebelião contra poderes totalitários, contra poderes definidores e modelos de mundo ideológicos, para os quais a subordinação dos detalhes, do objeto individual resistente ao 'todo' é decisivo. (TRAUMANN 2011: 3).

É importante salientar que essa "poética das coisas" não se encontra somente em sua obra ficcional propriamente dita, mas está muito presente em todos os ensaios da autora. No ensaio "Em cada língua estão fincados outros olhos", ela declara: “[d]esde sempre dei importância aos objetos. Sua aparência tanto fazia parte da imagem das pessoas que os possuíam, quanto as próprias pessoas.” (MüLLER 2003: 15). Como exemplo para essa afirmação, a autora menciona alguns objetos que a fazem lembrar de seu falecido pai: algumas pequenas chaves de fenda que ele guardava teimosamente na gaveta de talheres da mãe e que era motivo de briga entre os dois e os pés de abricó no quintal de casa, que para ela também eram teimosos, pois "não se envergonhavam de florescer." (MüLLER 2003: 16). Müller diz não ter uma explicação para essas conexões entre pessoas e objetos: “[m]uitas vezes se distribuem os sentimentos para fora de um modo estranho. Sobre alguns poucos objetos que sem razão alguma se prestam para explicar a lembrança na cabeça.” (MüLleR 2003: 16). Ainda no mesmo ensaio, Müller dá o exemplo dos chapéus com forro de seda branca que ela não suporta, por fazerem-na lembrar de dois agentes do serviço secreto que vieram importuná-la na fábrica em que

\footnotetext{
${ }^{26}$ Herta Müllers Poetik der Dinge é o título da dissertação de mestrado de Trautmann, na qual ele realiza um close reading muito esclarecedor sobre o significado dos objetos na obra da autora.
} 
Blume, R. - Herta Müller e o ensaísmo autobiográfico

trabalhava. Ao abordá-la, esses agentes tiraram seus gorros e ela, como forma de proteger-se, imaginou que o cérebro dos dois ficara preso ao forro branco. Essa ideia, por sua vez, deu-lhe certo sentimento de superioridade diante de seus opressores. Todos esses objetos vão sendo tecidos em sua complexa teia narrativa, transformando-se em imagens da opressão.

\subsection{As imagens de opressão}

Talvez essas imagens não tivessem me aparecido, se esses ventosos vizinhos, colegas de escritório, agentes do serviço secreto não tivessem trabalhado em prol do meu medo. (MÜLLER 2003: 195)

Os textos de Müller são ricos em imagens que surgem a partir de um modo muito particular de se relacionar com os objetos e as situações com as quais ela se depara. Com frequência a autora narra o modo como percebia certos objetos em sua infância, como no ensaio "Em cada língua estão fincados outros olhos". Essa percepção subjetiva cria imagens profundamente opressivas. Quando, por exemplo, era levada para dormir, assim que se apagava a luz, "a lareira azulejada ao lado da cama virava uma torre de água, aquela do fim do vilarejo com a uva brava.” (MüLLER 2003: 9). Ela narra que essas uvas possuíam uma tinta preta que se impregnava na pele. A partir desse dado, a imagem criada torna-se ameaçadora: “A torre de água ao lado da cama, suas uvas pretas como deve ser o sono profundo. Eu sabia que adormecer significava deixar-se afogar na tinta." (MÜLlER 2003: 10). O sono que deveria representar descanso para a criança, portanto, associa-se a uma imagem oprimente, "afogar na tinta" da uva brava, que a deixa tensa e desnorteada: "Mas eu também sabia: quem não consegue dormir é porque tem a consciência pesada, uma carga nociva no crânio. Portanto, era o que eu tinha, só não sabia por quê.”' (MÜLLER 2003: 10). Entretanto, a imagem criada pela criança não se limita ao seu mundo particular, mas se amplia para o vilarejo todo, que para ela igualmente se encontra mergulhado nessa opressão: “Também havia tinta lá fora, na noite do vilarejo. A torre mantinha a região sob seu controle, ela puxava o chão e o céu, e na tinta só existia, para todos no vilarejo, esse ínfimo lugar fixo no qual justamente se 
Blume, R. - Herta Müller e o ensaísmo autobiográfico

encontravam.” (MÜLLER 2003: 10). Essas imagens apontam para uma percepção infantil que ainda não consegue definir exatamente o que se passa em seu meio, mas que sente um profundo desconforto ali. E esse desconforto adquire traços claustrofóbicos na continuidade do texto: "De todas as direções os sapos coaxavam, os grilos faziam algazarra, mostravam o caminho para baixo da terra. E prendiam, para que ninguém escapasse, o vilarejo no eco de uma caixa.” (MüLLER 2003: 10).

Essa percepção do vilarejo como um ambiente hostil, fechado e controlado vai se confirmar à medida que a criança cresce e será identificado mais tarde como miniatura do Estado totalitário. Köhnen afirma que na obra de Müller "a realidade política é transformada em imagens." (KÖHNEN 2002: 19). Isso fica claro no exemplo acima. O teórico conecta a riqueza imagética da obra mülleriana ao olhar da autora que se coloca obstinadamente contra o "olho do poder", percebido por ela como onipresente.

É dessa tentativa de resistir ao olhar controlador da coletividade e de ver as coisas de outro modo que surgem essas imagens singulares que, além de seu teor político, tem uma dimensão artística: “[a] própria imagem figurativa já aponta para o caminho excêntrico no qual a linguagem não é mais apenas signo político, mas também estético." (KöHNEN 2002: 19). Sobre o modo como Herta Müller desenvolve esteticamente os conteúdos políticos, Katja SCHUBERT afirma: "Da destrutividade e da violência são extraídas, literalmente, as imagens linguísticas mais florescentes, as estruturas imagéticas caracterizam-se por uma grande abertura que libera os sentidos de qualquer controle, mergulhando o repulsivo na luz do belo" (SCHUBERT 2010: 115). Descrevendo, por exemplo, a falta de comunicação em sua infância, tanto na família quanto no vilarejo, a autora cria uma rede de imagens repleta de movimentos e de odores:

O falar sai voando, o calar fica e fica e cheira. Cheirava como o lugar na casa em que eu ficava ao lado de mim mesma, junto dos outros. No quintal, o calar cheirava a florescência de acácia ou a trevo recém ceifado, no quarto, a veneno de traça ou a uma série de marmelos sobre o armário, na cozinha, a massa ou a carne. Cada um carregava seus degraus na cabeça, sobre os quais o calar subia e descia. A pergunta "Em que você está pensando agora?" teria sido como um assalto. Era óbvio que se estava cheio de segredos. (MÜLLER 2003: 83) 
Blume, R. - Herta Müller e o ensaísmo autobiográfico

Schubert fala sobre a "escrita dos sentidos" de Müller a partir de uma análise de sua obra ficcional. Porém, essa escrita também aparece em certa medida nos ensaios, como mostra o exemplo acima, prendendo também ali os leitores na teia narrativa e fazendoos vivenciar, de certa forma, a estranheza, a angústia, o medo, o terror contido em suas imagens. Outro exemplo dessa escrita sinestésica encontra-se no ensaio "Se nos calamos, tornamo-nos desagradáveis - se falamos, tornamo-nos ridículos”. Todos os sentidos, o olhar, o olfato e o tato, tensos e paranóicos, configuram essa imagem amedrontadora da morte:

\begin{abstract}
Nos parques estava fincada a morte quando as folhas bem novas e levemente avermelhadas das alamedas de choupos cheiravam a quarto de gente velha. E a morte clara como cera também estava fincada na beira das estradas, em tílias florescentes, quando caía essa poeira amarela. Sobre o asfalto as tílias possuíam outro cheiro, havia inúmeras tílias no vilarejo, mas somente aqui na cidade, quando elas floresciam, me veio, ao cheirá-las, a palavra "açúcar de defunto". Também nos jardins em frente às casas das ruas secundárias a morte me procurava em grandes dálias que não conseguiam refrear suas cores nos polpudos botões enrolados. (MÜLLER 2003: 76)
\end{abstract}

Em uma análise dos ensaios de 1991 de Müller, LÜTZELER afirma que nesses textos "reflete-se o limite entre o realismo detalhista e uma realidade onírica ou que transborda para o surreal, a concomitância entre percepção de fatos e fantasia originada na cabeça." (LÜTZELLER 1994: 16). Essa mesma característica persiste no ensaísmo mais recente da escritora. Um exemplo é o já citado ensaio da coletânea de 2003, "Em cada língua estão fincados outros olhos", onde a autora rememora seu trabalho de cuidar das vacas no vale, quando criança, e o medo muito subjetivo que a envolvia:

Eu odiava o campo teimoso que devorava plantas e animais selvagens para alimentar plantas e animais domésticos. Cada campo era o panóptico ilimitado das formas de morrer, um florescente manjar de defuntos. Cada paisagem treinava a morte. Flores imitavam os pescoços, narizes, olhos, lábios, línguas, umbigos, mamilos das pessoas, não davam descanso, emprestavam as partes dos corpos em amarelo-cera, branco-cal, vermelho-sangue ou azul-manchado, desperdiçavam, acasalados com o verde, o que não lhes pertencia. Nos mortos, então, essas cores perpassavam a pele como queriam. Os vivos eram tão estúpidos e as exigiam, e nos mortos elas floresciam porque a carne abdicava. (MÜLLER 2003: 12) 
Blume, R. - Herta Müller e o ensaísmo autobiográfico

Sua memória se constrói a partir da narração de cenas comuns do cotidiano de um vilarejo que, entretanto, vão se transformando através de um olhar dissector que faz os detalhes crescerem e se distorcerem em imagens por vezes surreais. A natureza é percebida como extremamente hostil porque ela personifica a hostilidade da vida e das pessoas. E esses diferentes planos se intersectam e se distorcem na narrativa de Müller, gerando essas imagens surreais. Outro exemplo no mesmo ensaio são as pequenas chaves de fenda e os pés de abricó que lembravam o pai. A junção das duas coisas se distorce em uma imagem surreal: "Com os olhos eu adentrava as árvores de modo tão irracional que os galhos, ainda curtos e pelados, se pareciam incrivelmente com as pequenas chaves de fenda quando olhava muito tempo para as árvores." (MüLLER 2003: 16).

No ensaio "Se nos calamos, tornamo-nos desagradáveis - se falamos, tornamonos ridículos", a escritora descreve a sua técnica narrativa que transforma aquilo que se viveu em imagens verbais por vezes completamente redimensionadas:

Quando coloco o vivido nas frases, inicia-se uma mudança fantasmagórica. As entranhas dos fatos são empacotadas em palavras, elas aprendem a andar e se mudam para um lugar ainda desconhecido durante a mudança. Para continuar com a imagem da mudança, quando escrevo é como se a cama se colocasse numa floresta, a cadeira dentro de uma maçã, a rua corre para dentro de um dedo. Mas também é o contrário: a bolsa fica maior que a cidade, o branco do olho maior que a parede, o relógio de pulso maior que uma lua. (MÜLLER 2003: 85)

A focalização no detalhe e o seu redimensionamento produzem o surreal, fazem surgir as imagens da opressão, sensação coercitiva que a escritora explora não apenas teoricamente, mas também exemplifica amplamente em seus ensaios. O ensaísmo de Herta Müller ultrapassa a exposição teórico-poetológica de caráter explicativo, para apresentar-se muito mais como uma obra literária sobre literatura, que varia entre uma narratividade altamente subjetiva e imagética e a reflexão associativa sobre o papel da linguagem na sociedade. Referindo-se aos ensaios dos anos 1990, SCHAU afirma que "a recorrência a imagens mostra-se como constitutiva para a escrita teórica de Müller e seus principais conceitos.” (2003: 278). Esta é a característica que também se pode observar em seus ensaios de 2003, conforme se viu em alguns dos exemplos já citados acima. 
Blume, R. - Herta Müller e o ensaísmo autobiográfico

A partir do curioso título do ensaio que dá nome a essa coletânea, "O rei se inclina e mata", a autora tece uma complexa teia narrativa que constrói a memória de sua relação com a palavra "König” (rei), que para ela não provinha dos contos de fadas, mas do jogo de xadrez esculpido pelo seu avô nos tempos de prisioneiro de guerra e que, mais tarde, virou brinquedo da neta. De todas as figuras ela preferia o rei, embora este fosse um pouco cambaleante por estar velho e ter uma coroa meio desproporcional. A figura do rei sempre tivera para a neta uma conotação de poder, mesmo que difusa, que ela tentava vencer. A narração de um sonho que empresta novas dimensões à imagem do rei mostra claramente o que Trautmann (2011: 35) interpreta como tentativa da criança de desapoderar o rei:

Eu só sonhava coisas construídas louca e confusamente: abro a galinha e em seu ventre há uma caixinha cheia de figuras de xadrez, vermelhas e azuis ao invés de brancas e pretas. Elas são bem secas e duras, deveria ter sido audível elas chacoalharem quando a galinha ainda corria pela grama. Tiro as figuras de xadrez do ventre e coloco-as conforme as cores em duas fileiras. Há só um rei, ele cambaleia, se inclina. Ele é verde e fica vermelho enquanto se inclina. Eu o seguro na mão e sinto como o seu coração bate. Ele tem medo e por isso dou uma mordida nele. Por dentro ele é amarelo e macio, tem carne doce como um abricó, eu o como. (MüLLER, 2003:48-49)

Entretanto, fora do âmbito onírico o poder do rei só aumenta. Mais tarde a neta vai conhecer outro rei, o da cidade, que também é o rei do Estado. E ela compara:

O rei da aldeia "inclinava-se um pouco", ele cambaleava, como a região cambaleia. A gente vivia nessa região que consumia a si mesma, até consumir as pessoas também, até que elas morriam por si mesmas. Somente o rei da cidade ofereceu a segunda parte da frase: "o rei se inclina e mata". A ferramenta do rei da cidade é o medo. Não o medo da aldeia, construído na mente, mas um medo planejado, servido friamente, que estraçalha os nervos. (MÜLLER 2003: 51)

E um trecho esclarecedor, que talvez resuma essa imagem da opressão tecida de forma cada vez mais complexa e que mostra as suas várias dimensões é o seguinte:

O rei me seguiu primeiro da aldeia para a cidade, depois da Romênia para a Alemanha, como reflexo das coisas que para mim eram inexplicáveis. Ele personificava toda a extensão das coisas; quando não há mais palavra que sirva, nos descaminhos da mente, digo até hoje: olha aí, lá vem o rei. (MÜLLER 2003: 59) 
Blume, R. - Herta Müller e o ensaísmo autobiográfico

Para TRAUTMANN o rei "encarna a poética de Müller, que participa do enigmático 'reflexo' das coisas, ainda que 'nenhuma palavra sirva mais'.” (TRAUTMANN 2011: 38).

KÖHNEN discorre sobre o "encadeamento ideogramático de imagens” de Müller. Este surgiria a partir de um procedimento marcado "por arbitrariedade subjetiva, pela situação súbita," determinado "pelo isolamento de partes individuais de um decurso e sua recomposição.” (KÖHNEN 1997: 124). As imagens não representam, portanto, uma palavra ou conceito isolado, mas toda uma situação ou cadeia de situações construídas a partir de uma visão muito subjetiva. A imagem do rei é um bom exemplo de um ideograma mülleriano. A partir de uma vivência muito subjetiva vão se estabelecendo e se desdobrando as imagens que se encadeiam uma na outra "através de associações que são idiossincráticas e só se tornam 'legíveis' através do conhecimento do respectivo pano de fundo da experiência.” (KÖHNEN 1997: 124). Outro exemplo é a imagem das chaves de fenda que formam pequenos galhos no pé de abricó, já citada anteriormente, que também só se torna compreensível a partir da narração de diversas experiências da autora. Um terceiro exemplo é o da dália, no ensaio "Se nos calamos...", mencionado acima, em que uma flor se reveste de diferentes sentidos, conforme a situação. Como essa flor já fora símbolo de morte para a autora antes da perseguição política, a dália corporifica agora as diferentes situações, que tem igualmente algo a ver com a morte ou algo mortífero na ditadura:

Como devo explicar com palavras que a dália me dava uma atitude interna quase estável frente aos arrepelos de fora, que em uma dália assenta um interrogatório quando se vem do interrogatório, ou uma cela, quando uma pessoa de quem se gosta está na prisão. Que em uma dália está sentada uma criança quando se está grávida e não se quer ter essa criança de modo algum, porque não se tem a cara de pau de oferecer essa vida de merda a ela, mas que, caso seja descoberta, se vai para a prisão por aborto. (MÜLLER 2003: 77-78).

Conforme Köhnen esclarece a respeito da técnica figurativa de Müller, as metáforas em seus textos são constantemente "recodificadas e enriquecidas de novas experiências." (KÖHNEN 1997: 125). A ressignificação das coisas e das palavras a partir do 'olhar obstinadamente próprio' da autora cria essas imagens de opressão, fazendo com que elas acabem se colocando no lugar do indizível e a ajudem a realizar o desejo de "ser capaz de dizê-lo". (MüLLER 2003: 15). 
Blume, R. - Herta Müller e o ensaísmo autobiográfico

\section{Conclusão}

Para ScHAU a escrita poetológica de Herta Müller se aproxima "mesmo em suas metáforas centrais do discurso contemporâneo sobre autobiografia.” (SCHAU 2003: 46). Essa citação resume muito bem a discussão do presente artigo. Os ensaios de Müller ancoram-se, em primeiro lugar, muito marcadamente na vida da própria autora. Em segundo lugar, essas experiências de vida de modo algum apresentam-se como uma biografia que almeje qualquer completude ou inteireza, porém, trata-se sempre de uma escrita muito subjetiva e fragmentada.

O modo como a própria autora compreende a referencialidade desses textos foi apontado a partir da discussão a respeito do conceito de "percepção inventada" de Müller. Daí depreendeu-se que, mesmo em sua escrita ensaística, o autobiográfico não busca atender a uma exigência de verdade, mas, a partir do recurso da ficcionalização, atende antes a uma exigência de autenticidade. Em quarto lugar, tematizou-se o olhar muito próprio de Herta, que Apel considera "obstinadamente próprio", mostrando que a radicalidade desse olhar da autora tem o objetivo de se contrapor a uma visão comum à maioria, que é definido como "olho do poder" pela própria escritora. Ela mesma também fala sobre o "olhar estranho", que não adviria de sua procedência bicultural, mas de suas experiências traumáticas que lhe roubaram um olhar descontraído, imparcial. Desse modo, os leitores de Herta Müller defrontam-se em seus textos com um olhar muito incomum sobre as coisas e as situações.

Os dois últimos itens concentraram-se mais fortemente na construção estética dos textos autobiográficos de Müller. No item cinco, foi apontada a importância das coisas na construção literária da autora, coisas ou objetos simples provindos do seu cotidiano que, entretanto, nas mais diferentes situações perdem seu significado original no contato ou confronto com o poder. Por último, explanou-se como essas coisas ou objetos servem à autora para criar uma rica variação de imagens de teor sinestésico, surreal ou mesmo ideogramático, perseguindo sempre o objetivo de colocar em palavras os muitos momentos de opressão de sua vida. 
Blume, R. - Herta Müller e o ensaísmo autobiográfico

Em um dos poucos ensaios em que Herta Müller não fala sobre sua própria vida, mas sobre a de um escritor e de duas escritoras ${ }^{27}$ que, como ela, viveram situações de perseguição política extrema e cujas obras, marcadamente autobiográficas, admira muito, ela resume a importância dessa escrita dizendo que "[o] individual, enquanto caso exemplar para fatos acontecidos aos milhares, é e continua sendo imprescindível." (MüLLER 1996: 5).

É o que OTTMERS afirma a respeito da escrita autobiográfica de Herta, quando diz que ela não objetiva "um mero espelhamento de si mesma", mas que "a forma estética, a linguagem figurativa e a estrutura aberta dos [seus] textos permite expressar experiências comuns (e sociais) nas experiências próprias." ${ }^{28}$. É o que o teórico qualifica como "uma privacidade, que é política" (OTTMERS 1994: 292).

Essa conjugação de estético e político na obra de Herta Müller configura-se, conforme também postulam Apel, Haines e Köhnen, citados acima, como característica central não somente de seus romances e contos, mas, como se procurou mostrar aqui, de seus ensaios. Embora realizado em uma forma textual que, tradicionalmente, é mais teórico-reflexiva, seu ensaísmo apresenta-se aqui como uma textualidade híbrida, em que a narração da experiência pessoal, do autobiográfico, do privado, alimenta um dizer sobre a criação literária e sobre as suas condições em regimes de opressão.

\section{Referências bibliográficas}

APEL, Friedmar. Schreiben, Trennen. Zur Poetik des eigensinnigen Blicks bei Herta

Müller. In: EKE, Norbert Otto (Hg.). Die erfundene Wahrnehmung. Annäherung an Herta Müller. Paderborn: Igel, 1991, p. 22-31.

APEL, Friedmar. Wahrheit und Eigensinn. Herta Müllers Poetik der einen Welt. In: ARNOLD, Heinz Ludwig. Text + Kritik. Herta Müller. Heft 155, Juli 2002, p. 39-48.

BECKER, Jurek. Warnung vor dem Schriftsteller. Drei Vorlesungen in Frankfurt.Frankfurt: Suhrkamp, 1990.

\footnotetext{
${ }^{27}$ Trata-se de Theodor Kramer, Ruth Klüger e Inge Müller.

${ }^{28}$ Ao falar, em suas conferências sobre poética na Universidade de Frankfurt em 2009, sobre o autobiográfico em sua obra, Uwe Timm afirma: "A reflexão voltada para memória social é o que perfaz o aspecto público, sim, necessariamente político da literatura, que parte das experiências individuais do autor, para ultrapassá-las. Um trabalho de memória que ao mesmo tempo também é trabalho de escrita.“ (TIMM 2009: 83).
} 
Blume, R. - Herta Müller e o ensaísmo autobiográfico

BIENEK, Horst. Das allmähliche Ersticken von Schreien. Sprache und Exil heute. München: Hanser, 1987.

EKE, Norbert Otto. Augen/Blicke oder: Die Wahrnehmung der Welt in den Bildern. Annäherung an Herta Müller. In: __ (Hg.). Die erfundene Wahrnehmung. Annäherung an Herta Müller. Paderborn: Igel, 1991, p. 7-21.

HAINES, Brigid; LITTLER, Margaret. Gespräch mit Herta Müller. In: HAINES, Brigid (ed.). Herta Müller. Cardiff: University of Wales Press, 1998, p.14-25.

HAINES, Brigid; LITTLER, Margaret. 'Leben wir im Detail': Herta Müller's Micro-Politics of Resistance. In: HAINES, Brigid (ed.). Herta Müller. Cardiff: University of Wales Press, 1998, p.14-25.

HOLDENRIED, Michaela. Im Spiegel ein anderer. Erfahrungskrise und Subjektdiskurs im modernen autobiographischen Roman. Heidelberg: Carl Winter. Universitätsverlag, 1991.

HolDENRIED, Michaela Autobiographie. Stuttgart: Reclam, 2000.

HopPE, Felicitas. Sieben Schätze. Augsburger Vorlesungen. Frankfurt a.M.: Fischer, 2009.

KöHNEN, Ralph (Hg.). Der Druck der Erfahrung treibt die Sprache in die Dichtung. Bildlichkeit in Texten Herta Müllers. Frankfurt a.M.: Peter Lang, 1997.

KöHNEN, Ralph. Terror und Spiel. Der autofiktionale Impuls in frühenTexten Herta Müllers. In: Arnold, Heinz Ludwig. Text + Kritik. Herta Müller. Heft 155, Juli 2002, p. 18-29.

LeWITSCHAROFF, Sibylle. Vom Guten, Wahren und Schönen. Berlin: Suhrkamp, 2012.

LÜTZELER, Paul Michael. (Hg.). Einleitung: Poetikvorlesungen und Postmoderne. In: LÜTZELER, Paul Michael. Poetik der Autoren. Beiträge zur deutschsprachigen Gegenwartsliteratur. Frankfurt a. M.: Fischer, 1994, p. 7-19.

MidgleY, David. Remembered Things: The Representation of Memory and Separation in Der Mensch ist ein grosser Fasan auf der Welt. In: HAINES, Brigid (ed.). Herta Müller. Cardiff: University of Wales Press, 1998, p.25-35.

MÜLLER, Herta. Der Teufel sitzt im Spiegel. Wie Wahrnehmung sich erfindet. [ensaios] Berlin: Rotbuch, 1991.

MÜLLER, Herta. Hunger und Seide. Reinbeck bei Hamburg: Rowohlt, 1995.

MÜLLER, Herta. In der Falle. Göttingen: Wallstein, 1996.

MÜLLER, Herta. Der König verneigt sich und tötet. München - Wien: Carl Hanser, 2003.

MÜLLER, Herta. O compromisso. Tradução de Lya Luft. São Paulo: Globo, 2012.

OTTMERS, Clemens. Schreiben und Leben. Herta Müller, Der Teufel sitzt im Spiegel. Wie Wahrnehmung sich erfindet. In: LÜTZELER, Paul Michael (Hg.). Poetik der Autoren. Beiträge zur deutschsprachigen Gegenwartsliteratur. Frankfurt a. M.: Fischer, 1994, p. 279-294.

SANDBERG, Beatrice. Autobiographisches Schreiben - Gedanken zur Übertragung von Leben in Literatur. In: ALBRECHT, Jörn / GERZYMISCH-ARBOGAST, Heidrun / ROTHFUSSBASTIAN, Dorothee. Forschungsfragen in der Diskussion: Festschrift für Werner Koller. Tübingen: Gunter Narr, 2004, p.163-183.

SCHAU, Astrid. Leben ohne Grund. Konstruktion kultureller Identität bei Werner Söllner, Rolf Bossert und Herta Müller. Bielefeld: AisthesisVerlag, 2003. 
Blume, R. - Herta Müller e o ensaísmo autobiográfico

SCHUBERT, Katja. "Ich habe in meinen Büchern noch keinen Satz auf rumänisch geschrieben aber selbstverständlich schreibt das Rumänische immer mit."Anmerkungen zu Texten von Herta Müller. In: Asholt, Wolfgang; HoOCK-DEMARLE, Marie-Claire; KoIRAN, Linda; SCHUBERT, Katja (Hrsg.). Littérature(s) sans domicile fixe. Literaturen ohne festen Wohnsitz. Tübingen: Gunter Narr, 2010, p.115-125.

SMith, Sidonie, Watson, Julia. Reading Autobiographie: A Guide for Interpreting Live Narratives. Minneapolis: University of Minnesota Press, 2010, 2nd ed.

STEINMAYR, Markus. "Ich wollte in der Tiefe der Bilder verschwinden" - Bildlichkeit als Lust am Text. EinVersuch über Der Teufel sitzt im Spiegel. In: KöHNEN, Ralph (Hg.) Der Druck der Erfahrung treibt die Sprache in die Dichtung. Bildlichkeit in Texten Herta Müllers. Frankfurt a. M.: Peter Lang, 1997.

TIMM, Uwe. Von Anfang und Ende. Über die Lesbarkeit der Welt. Frankfurter Poetikvorlesungen. Köln: Kiepenheuer\&Witsch, 2009.

Trautmann, Simon. Herta Müllers Poetik der Dinge. Masterarbeit, Universität Hamburg, 2011.

WAGNER-EGElHAAF, Martina. Autobiographie. Stuttgart; Weimar: Metzler, 2000.

WoHLLEBEN, Doren. Schwindel der Wahrheit. Ethik und Ästhetik der Lüge in PoetikVorlesungen und Romanen der Gegenwart. Freiburg i. Br. / Berlin: Rombach, 2005.

Recebido em 16/02/2013

Aprovado em 24/03/2013 